\title{
HERMANN SOMMER AND HIS ARCHAEOLOGICAL LEGACY. THE PRESERVATION OF CULTURAL MONUMENTS ON THE SAMBIAN PENINSULA IN THE PERIOD 1929 TO 1945
}

\author{
JAROSLAW A. PRASSOLOW*
}

Zentrum für Baltische und Skandinavische Archäologie Stiftung Schleswig-Holsteinische Landesmuseen Schloss Gottorf, DE-24837, Schleswig, Germany

Institute of Archaeology of the Russian Academy of Sciences, Dmitriia Ul'ianova St 19 RU-117036, Moscow, Russia

\section{Keywords}

East Prussia, Fischhausen district, Fischhausen Archive, Hermann Sommer, Lochstedt Castle, monument preservation, archival materials, reconstruction of archaeological landscape

\begin{abstract}
The article is devoted to the scientific and organisational activities of Hermann Sommer (18991962), the founder and head of the Office for the Care and Preservation of the Cultural Heritage in the Fischhausen district of the German province of East Prussia, during the difficult period of Germany's history from 1929 to 1945 . It describes the circumstances surrounding the creation, as well as the later rescue and finally rediscovery by the archaeological community, of Sommer's historical and archaeological legacy. One of the most important components of the archaeological part of the heritage is the Fischhausen Archive, a card-index archive of archaeological monuments that were known in the district in question by 1945. By this time, the first experience of using the data from the archive had already demonstrated the enormous potential of these documents for the reconstruction of the prewar state of research, as well as for the modern study of the archaeological sites on the Kaliningrad Peninsula. The search for the rest of his legacy has already resulted in a number of unexpected discoveries of further archaeological material. Preliminary results also indicate that similar archives of archaeological monuments could also have been created for other districts of the former German province of East Prussia.
\end{abstract}

\section{Introduction}

Researchers into the antiquities of the Kaliningrad Peninsula (before 1946 known as the Sambian Peninsula) work in a unique situation: the subject of their studies is not only ancient artefacts and monuments, but also the results of the archaeological research that took place in the prewar period. It is fair to say that the archaeology of the region has a two-layer structure, and its second 'historiographic', layer is often no less interesting and distinctive than the monuments themselves. Undoubtedly, the study of the history of archaeological research is also practiced in other regions; however, it is here, in the former East Prussia, that this trend is expressed so vividly. The current knowledge of the relatively recent and significant prewar period of research in the region is severely affected by the Second World War: many once important names and events have almost completely faded from the memory of our contemporaries and colleagues. Fortunately, thanks to the rediscovery of preserved parts of prewar collections and archives in the early 1990s and their reintroduction into scientific research, the renewed interest of archaeologists in the region's past, and, last but definitely not least,

\footnotetext{
*E-mail: jaroslaw.prassolow@zbsa.eu
} 
due to international cooperation in this field of research, this loss of knowledge was first halted and then reversed.

Many significant and still partially preserved archaeological monuments on the peninsula have a rich prewar history of study. At the same time, it is well known that archaeological excavations of many categories of archaeological monuments in fact result in their partial and even complete physical disappearance. Therefore, it is not surprising that the key to understanding the monuments studied today often lies in the old excavation reports and diaries of their first researchers. As we subsequently go deeper into these prewar data sources, the images of the 19 th and early 20th century researchers become more and more vivid on the yellowed pages of old publications and archival documents.

This article was originally conceived by the author as a scientific review of the content and research potential of an important, and until now unpublished, archive. As work on the material progressed, it became increasingly clear that, prior to the publication of archaeological data of direct practical value, it was necessary to introduce the reader to the historical events and (geo)political context that preceded and accompanied the creation of the archaeological source in question, as well as to describe the circumstances of its preservation and rescue during the Second World War and the postwar period. Finally, the history of its recent 'rediscovery' and presentation to the modern archaeological community should be told. However, it should be mentioned that, in spite of the accuracy of the data presented in the article, a number of important aspects should still be clarified in the future. ${ }^{1}$ This applies both to the reconstruction of the relevant historical background of the events in question, as well as to the clarification of the storage locations and the state and contents of the corresponding archival materials, which are yet to be introduced into the research. This article is thus introductory in nature, while the results of the direct analysis of the archaeological data from the archive in question, as well as their research significance, will be discussed in a further publication.

\section{The archives of Rudolf Grenz and} Hermann Sommer at Gottorf Castle

The Museum of Archaeology ${ }^{2}$ of the German federal state of Schleswig-Holstein, located in Gottorf Castle, is well known to archaeologists and antiquities researchers of the former German province of East Prussia. The archive of the German researcher Rudolf Grenz (1929-2000) has been kept there since 2003. It is the most significant post-

\footnotetext{
1 The author is currently carrying out an active search in this direction.

2 Museum für Archäologie Schloss Gottorf, until 2017 Archäologisches Landesmuseum Schloss Gottorf.
}

war collection of documents on the archaeology of East Prussia, and has not lost its scientific significance, even since the rediscovery of the archive of the Prussia-Museum in the early 1990s (Reich 2009; Reich and Menghin 2008). According to the idea of its creator, the archive combines extremely diverse data sources that were available to him in the postwar period: prewar publications in scientific and popular journals and newspapers; excavation reports; maps and plans; correspondence between researchers, museum workers and owners of plots of land; sketches and photographs of finds, grave complexes and entire burial sites and other archaeological monuments, etc. In the 1960s to 1990s, this analogue database of archaeological data was an attempt to reconstruct the prewar pool of information, essentially an archaeological encyclopedia of the province of East Prussia.

While much of the data presented in the Grenz Archive can be found in the form of original journal publications in the libraries of museums and research and educational institutions elsewhere in the world, the prewar sketch maps of the archaeological monuments in the Fischhau$\operatorname{sen}^{3}$ district $(\text { Kreis })^{4}$ of East Prussia, situated on the Sambian Peninsula, are especially valuable in the context of their uniqueness. These sketch maps were drawn on the basis of topographical maps (Meßtischblätter, scale 1:25000), and their absolute majority remained unpublished during the prewar period. Their origin is, however, not the archive of Grenz, but the finds card-index (Fundkartei) archive, also known as the Fischhausen Archive or the Hermann Sommer Archive (Fig. 1). The original is virtually unknown to modern archaeologists, and consists of four volumes ${ }^{5}$ that have been kept at Gottorf Castle since 2006, when they were handed over to the Archaeological Federal State Museum (Archäologisches Landesmuseum Schloss Gottorf), located in the same castle, for permanent storage by the Kreisgemeinschaft Fischhausen, local community of the former administrative district of Fischhausen ${ }^{6}$ (hereinafter referred to as the Fischhausen Community). ${ }^{7}$

The true scientific significance of Sommer's archive became apparent only a few years ago in the framework of a scientific project devoted to the reconstruction of the prewar state of archaeological research in the former East Prussia, and, inter alia, to the re-identification

\footnotetext{
On 1 May 1939, the administrative districts of Fischhausen and Königsberg were combined to form the new district of Samland in the province of East Prussia.

4 Translations by the author.

5 Volume I contains data on archaeological sites in the Fischhausen district whose names begin with A-K, Volume II with K-P, Volume III with R-U, and Volume IV with W-Z.

6 The former inhabitants, repatriated 1946 in modern Germany. The author expresses his sincere gratitude to Dr Volker Hilberg for providing detailed information on the circumstances of the hand-over of Sommer's archive.
} 


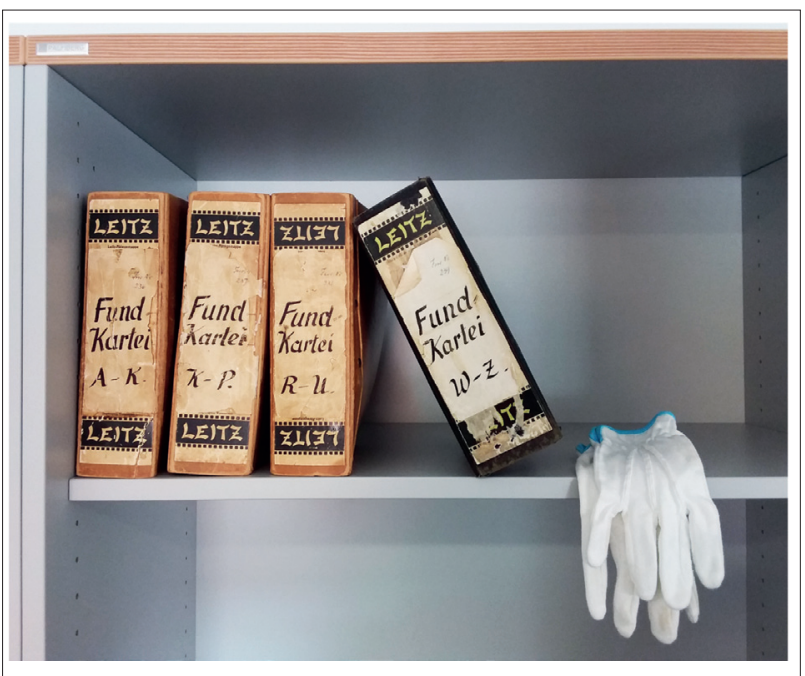

Figure 1. The four volumes of Hermann Sommer's Fischhausen Archive in the Museum of Archaeology, Gottorf Castle, Germany (photograph by J.A. Prassolow).

of the archaeological monuments known until $1945^{8}$ on the Sambian Peninsula (von Carnap-Bornheim et al., 2012; Prassolow, Ibsen 2015; Ibsen et al., 2017). Already the first acquaintance with this source demonstrated its high research potential, even in comparison with the rediscovered parts of the Prussia-Museum's archive, as far as the total number of archaeological monuments and their exact locations in the Fischhausen district are concerned.

The unique data contained in Sommer's archive will certainly occupy a worthy place in future publications on the archaeology of the former East Prussia, and, in the case of many monuments, will serve as a basis for their further investigation. That said, the author would like to stress that the present publication is primarily intended to serve as an introduction: we will consider the peculiarities of the social-historical processes relevant to the development of archaeology in the province at the end of the 1920s, and the circumstances of the creation, development and rescue of the archive and further related archaeological materials. We will also become acquainted with the East Prussian archaeologist and local historian Hermann Sommer, the compiler of the archive, who is little known in the modern archaeological community. A number of extremely curious, and previously unknown to a wide range of readers, data are taken from, if not indicated otherwise, an unpublished report by Sommer himself (Sommer 1956), which until recently was kept in the museum's archive of the Fischhausen Community in the city of Pinneberg, Germany.

\footnotetext{
8 For detailed information on the research project in question, see www.akademieprojekt-baltikum.de.
}

The geopolitical position of East Prussia in the late $1920 \mathrm{~s}$

One of the consequences of Germany's defeat in the First World War was the loss of a significant part of its territory (about $13 \%$, or more than 43,200 sq. km). According to the Treaty of Versailles, in Eastern Europe Germany lost the city of Posen (Poznan), and part of Upper Silesia, Pomerania and West Prussia, to Poland. Danzig (Gdansk) received the status of a 'free city', under the protection of the League of Nations; it no longer had any common borders with the rest of Germany. The Hlučín region became part of Czechoslovakia; and Memelland (in Lithuanian, Klaipedos kraštas), the part of East Prussia north of the River Memel (Nemunas), first came under the control of the League of Nations, was temporarily put under French administration, and finally became part of Lithuania in 1923.

Given the bitterness between the warring parties in the First World War, and the fact that from 1919, East Prussia no longer had any common borders with the rest of Germany, and in fact became an enclave, it is not surprising that the mentality in the province (especially in patriotic and revisionist-minded strata of its population) even ten years after the end of the war, was that of a fortress besieged on all sides. In a never-before-published manuscript, completed in 1956, the East Prussian archaeologist and local historian Hermann Sommer describes in detail the public mood of the late 1920s. There were strong concerns that the victorious states in the First World War were planning to further alienate the territories of the 'East German lands', and in particular, East Prussia. Sommer believed that agents of foreign powers, who according to him were part of an extensive network, bought Medieval German documents testifying to the 'Germanic origin' of the population of the province with foreign currency, and then secretly exported them abroad. The final goal was to create the appearance that Germany's claims to the territory in question were unreasonable (cf. Wagner 2019, pp. 231-232). At the same time, the assumed ongoing falsification of historical events of the Middle Ages was supposed to strengthen the hypothesis of the Slavic nature of the local population, and accordingly to serve as a basis for the hand-over of East Prussian lands to Poland (Sommer 1956, pp. 1-3).

Sommer further notes in his manuscript that the situation with the destruction of the historical and cultural heritage of East Prussia was exacerbated by rising inflation and the resulting impoverishment of aristocratic families, which forced them to sell off antiques and art from their households. The mass buying up of these valuables by traders, and their further sale abroad, led to irrevocable cultural losses for the inhabitants of East Prussia as a whole, and 
for researchers into its antiquities in particular (Sommer 1956, pp. 1-3).

One more danger that directly threatened the archaeological monuments of East Prussia was the growing tendency to divide large land holdings into smaller plots of land, while the new colonists in East Prussia were often far from understanding the specifics of the historical and archaeological heritage of the province. As a result, the agricultural and infrastructural development of land was often conducted by the colonists without regard for the preservation of archaeological monuments. For example, Bronze Age barrows in the forests, which until recently had been part of large estates, were now in danger. A characteristic feature of the East Prussian mounds is the presence of stone pavements, which made them man-made 'deposits' of stones, used in large quantities for paving roads, constructing buildings and railway embankments, and so on. Whereas previously the stones were 'mined' from easily accessible barrow mounds in open terrain, now it was possibly the turn of the barrow mounds in the forests of East Prussia (Sommer 1956, p. 5; Fischer 2000, p. 69).

The establishment of the Office for the Care and Preservation of the Cultural Heritage and its functions

For both academic and political reasons, the provincial government decided to take urgent action to counter the loss of East Prussia's cultural and historical heritage (cf. Dunker 1927, pp. 33-34). Dr Max Hein, the director of the Prussian State Archive (Preußisches Staatsarchiv) and Dr Wilhelm Gaerte, the director of the Provincial Museum of East Prussia (Provinzialmuseum von Ostpreußen 'Prussia'), ${ }^{9}$ who had already been responsible for the preservation of the East Prussian cultural heritage, took an active part in this decision. Gaerte directly supervised the creation of a circle of trustees (Vertrauensmännerkreis, ${ }^{10}$

9 In spite of several renamings in the first half of the 20th century, it is most widely known under the name 'Prussia-Museum?

${ }^{10}$ These numerous volunteer assistants recruited from the ranks of teachers, civil servants, etc, should not be confused with the senior officials at a provincial level responsible for the preservation of natural and cultural monuments. These were named from 26 March 1914 (the adoption of the Prussian Excavation Law, Preußisches Ausgrabungsgesetz) Vertrauensmänner für kulturgeschichtliche Bodenaltertümer der Provinz Ostpreußen, and from 30 July 1920 (a supplement to the law) Staatliche Vertrauensmänner für die Archäologie, as well as being occasionally referred to as Vertrauensmänner für kultur- und naturgeschichtliche Bodenaltertümer. The functions of these responsible officials were performed in East Prussia at different times by such eminent archaeologists as Max Ebert (one of his two representatives was Heinrich Kemke), Gaerte and La Baume (with Otto Kleemann and Dietrich Bohnsack as his representatives) (Jahn 1927a, p. 2; 1927b, pp. 35-36, La Baume 1942, p. 29; Nowakowski 2000, pp. 202-204; 2004, pp. also known as Kreispfleger) with a special scientific and technical education, who were responsible for the preservation and investigation of archaeological sites throughout the whole province. ${ }^{11}$ In addition, their task was to educate the public about the value of cultural, archaeological and ethnographic monuments, and the urgent need to preserve them (cf. Jahn 1927b, p. 35). The logical continuation of this trend was the decision made in October 1928 by the council (Kreistag) of the Fischhausen district (Fig. 2) to establish an Office for the Care and Preservation of the Cultural Heritage (Dienststelle zur Pflege und Erhaltung der Kulturgüter), ${ }^{12}$ which was to work in close cooperation with other research, archival and museum institutions in the province (Sommer 1956, p. 5).

According to the decision, the new Office in the Fischhausen district, which at that time included two cities and 102 municipalities (Gemeinde), had several areas of activity. The most interesting of these, regarding the modern reconstruction of the archaeological landscape in the area in question, was 'the preservation of cultural [i.e. archaeological] and natural monuments' (Kultur- und naturgeschichtliche Bodenaltertümer). ${ }^{13}$ This is how Sommer described the range of tasks assigned to the Office in this field: 'Years of research conducted by the Prussia-Museum since 1850 have identified a number of municipalities within the district with prehistoric burial sites from all periods of time. These were investigated only partially, and were in imminent danger of destruction due to ploughing. The insufficient quality of methods of archaeological excavation and research prior to the First World War led to significant gaps in accurate mapping and dating. Based on his own research experience over the previous eight years, the undersigned, upon taking office, paid particular attention to this issue in his service report.

'Altogether, 55 settlements from all prehistoric and early historical periods, as well as about 200 burial sites, were known in an area of 80 municipalities. Their preservation, description and subsequent study were already an enormous task in themselves. In addition, the Bronze Age barrow mounds, which were of particular interest to stone mining companies, were in great danger'. (Sommer 1956, pp. 4-5). In order to prevent the destruction of the monuments, and at the same time to educate the population of the province, it was agreed to work closely with the police, the local administration, and also from 1938 with the Land Department for Ancient History (Landesamt für Vorgeschichte) (Wagner 2019, pp. 319-321).

78-79; Hoffmann 2019, p. 77, p. 82; Wagner 2019, pp. 234237, p. 321).

${ }^{11}$ Similar actions were undertaken by Hein with regard to archival sources. These are, however, not relevant to the topic of this publication.

${ }_{12}^{12}$ Hereinafter referred to as the Office.

${ }^{13}$ The designations of the fields of activity are given according to the original manuscript by Sommer (1956, pp. 4-9). 


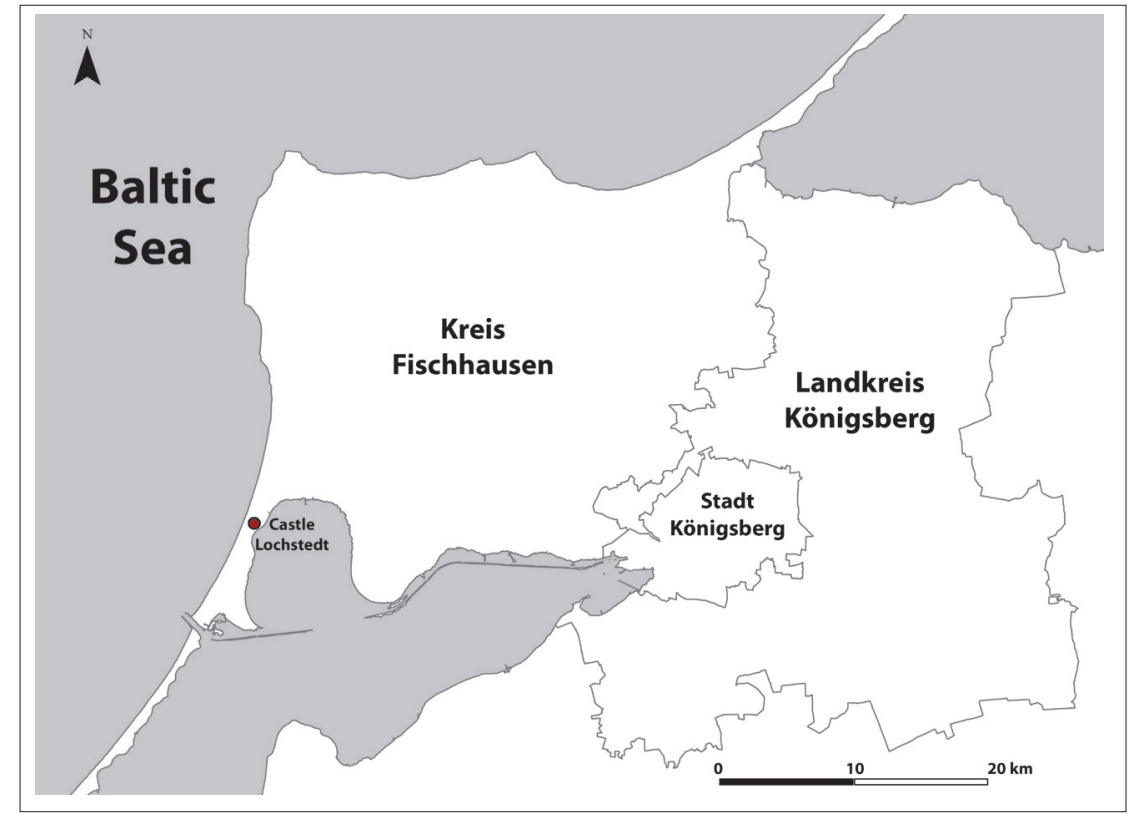

Figure 2. The administrative districts of Fischhausen and Königsberg in the province of East Prussia, which were combined in 1939 to form the new district of Samland (drawn by J. Nowotny).

The next important area of the Office's activity was 'nature protection, landscape conservation' (Naturschutz, Landschaftspflege). The goal was to protect both the natural features of the local landscape (its two bays and spits, shifting dunes and rare species of trees), and its characteristic elements of anthropogenic origin, such as ancient settlement sites, sacred Prussian groves, 'sacrificial stones', and so on.

Equally important was the implementation of activities in the field of the 'preservation of monuments of architecture' (Die bauliche Denkmalpflege), numerous monuments of secular Medieval, Teutonic Order and Church architecture, as well as decorative elements of the buildings, such as wall paintings and frescoes. Finally, it was planned to prevent the uncontrolled sale of cultural objects and antiquities from neglected and/or sold estates and old peasant households (Sommer 1956, p. 6).

In the light of the complicated geopolitical situation described above, great importance was attached to the activities of the Office in the area of the acquisition and preservation of Medieval documents, archives and other written sources (Archivpflege), as confirmation of Germany's right to the territory of East Prussia. At the same time, it was planned to conduct educational work with local people in order to stop the sale of relevant documents and the like to antique dealers. Both of these activities were to be carried out in close cooperation with the Prussian State Archive.

Finally, it was the Office's responsibility to stimulate and organise international tourism in the province, as an important factor in its economic development.
Taking into account the importance of the decision of the district council, the establishment of the Office had already been officially entrusted to Sommer by May 1929 (Fig. 3). In January 1930, on the completion of the necessary organisational proceedings, he was appointed head of the Office. ${ }^{14}$ In addition to institutions such as the Königsberg Provincial Museum 'Prussia' (director Adalbert Gaerte), the Provincial Monument Department (Provinzialdenkmalamt) (director Richard Detlefsen), and the Königsberg Prussian State Archive (director Hein), the Office for the Care and Preservation of the Cultural Heritage became the fourth institution directly responsible for the preservation of the historical and archaeological heritage in the Fischhausen district. ${ }^{15}$ In March 1930, the above-mentioned institutions officially signed an agreement on the division of their areas of activity and the interaction between them. It seems highly probable that the need for the establishment of the Office was dictated by the inefficiency, or rather the objectively limited capacity, of the Provincial Monument Department, with regard to the preservation and study of archaeological monuments (Hoffmann 2018, pp. 77-79, 82; Grunwald 2019, pp. 237-238).

Bearing in mind the importance, urgency and scope of the tasks set for the Office, as well as the high status of its actual founders and partners, it is obvious that it could only be headed by a professional who was well acquainted

\footnotetext{
${ }^{14}$ Sommer mentions in his manuscript that a number of other districts in East Prussia also followed the example of Fischhausen. Their list, as well as more detailed information, is yet to be determined through further research.

${ }^{15}$ The Office was partly funded by the district of Fischhausen, and partly through donations, '... which the undersigned received for collaborative activities with various scientific institutions' (Sommer 1956, p. 10).
} 


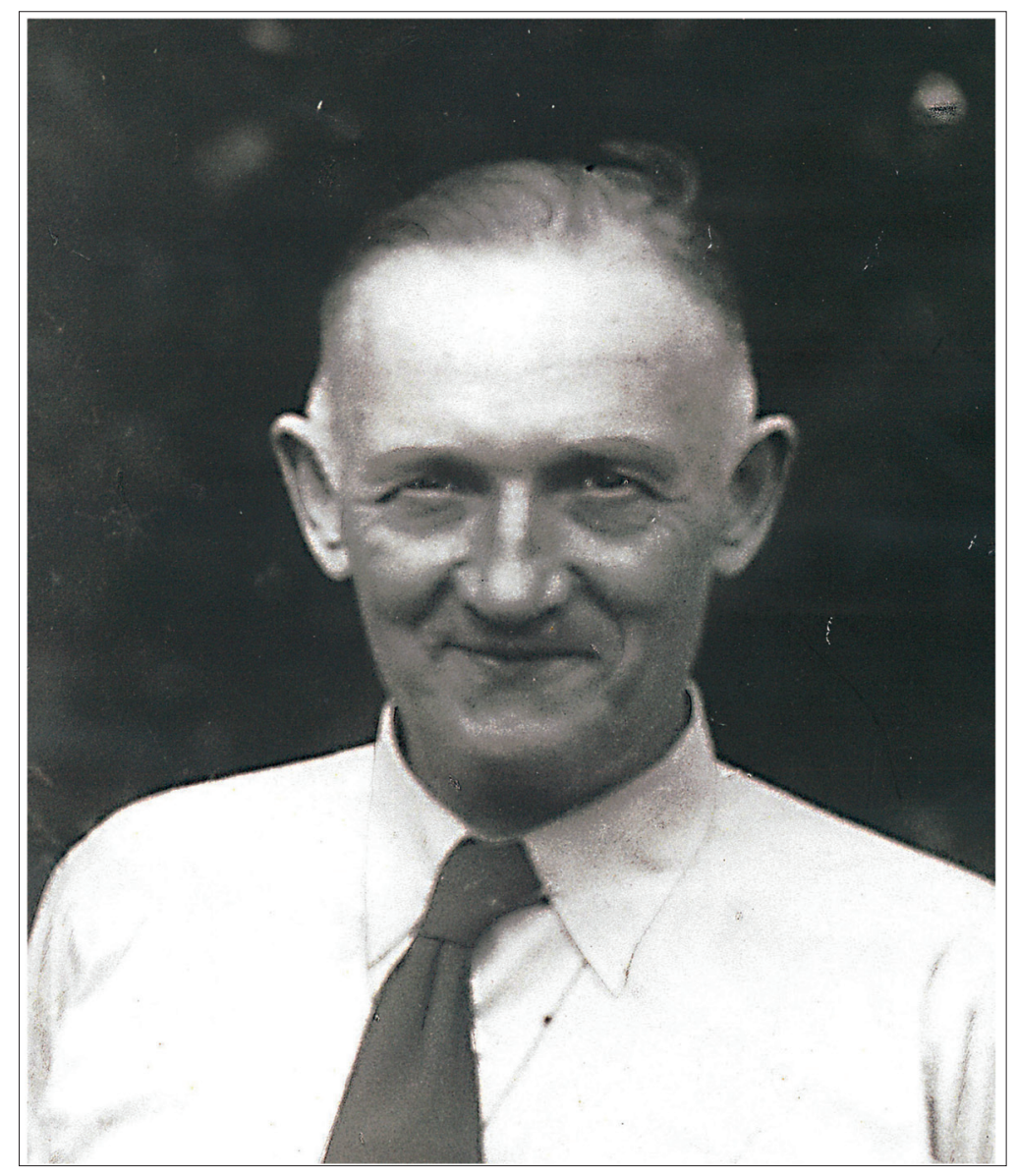

Figure 3. Hermann Sommer, the East Prussian archaeologist and historian, head of the Office for the Care and Preservation of the Cultural Heritage (photograph from the family album of the researcher's daughter, M. Huuck).

with questions of the preservation of archaeological monuments on the Sambian Peninsula, and who could also command authority and trust in the relevant archaeological and museum circles. Although the name of Sommer is regularly mentioned in the documents of the PrussiaMuseum archive, it means almost nothing to most modern archaeologists. So who was the person appointed head of the Office for the Care and Preservation of the Cultural Heritage in one of the most important districts of East Prussia?

\section{Sommer's career until 1929}

Many facts in the life of Hermann Sommer (1889-1962) have yet to be clarified. The information we have today comes mainly from two sources: the personal papers and work records of the archaeologist, which until recently had been kept in the museum archive of the Fischhausen Community, and documents passed on by his family, and their oral reports. ${ }^{16}$

\footnotetext{
${ }^{16}$ In this regard, the author would like to warmly thank Sommer's daughter Marianne Huuck, and his son Hans-Georg Sommer, for sharing the archival and personal documents of their father, as well as for their constant hospitality. I am
}

Sommer was born in 1889 in Königsberg into the family of an insurance agent. He is known to have studied landscape gardening and forestry between 1913 and 1915(?). In 1917, like many of his future fellow researchers of antiquities, he was drafted into the Kaiser's army (Reichsheer), and fought on the Western Front in a machine-gun company, in bloody battles such as the Battle of the Marne, the Battle of Soisssons-Reims, the Battle of the Argonne Forest, and many others. After the end of the First World War and his demobilisation from the army, Sommer studied archaeology as an external student (1924-1929). His supervisor was probably Gaerte, ${ }^{17}$ who inter alia gave courses for archaeologists and local historians (Wagner 2019, pp. 235-236). In the same period (from the beginning of the 1920s), Sommer worked for the Central Agricultural Association of Königsberg, and according to an indirect indication in his already-mentioned manuscript, participated in archaeological excavations. He continued to develop his skills, even after his appointment as head

also thankful to Wolfgang Sopha, the head of the Fischhausen Community, and to Heidrun Meller and Uwe Nietzelt, members of the Community, for their assistance in finding materials from Sommer's legacy in the Pinneberg museum archive.

${ }^{17}$ Marianne Huuck, personal communication. 
of the Office. From 1929 to 1933 in particular, he attended additional lectures and practical classes in archaeology given by Professor Wolfgang La Baume, with whom he maintained close working relations ${ }^{18}$ in the following years, which also led to continued friendly relations after the end of the Second World War. ${ }^{19}$

\section{The activities of the Office between} 1930 and 1939

The Office was housed in Lochstedt (Lochstädt) Castle, which was founded in 1270 as a residence of the Commander (Komtur) of the Teutonic Order on the shore of the modern Kaliningrad Bay (Frisches-Haff) (Bakhtin 2005, p. 112) (Figs. 2, 4, 5). Despite the rather poor condition of the castle at the time, it was still the best-preserved building of the Order in the Fischhausen district. In 1896, Medieval frescoes were discovered in the castle, which led to the establishment of the district museum and archive in Lochstedt (Samländisches Kreisarchiv und Museum) in 1928.

\section{The popularisation of archaeology and enlightenment}

Immediately after taking office, Sommer began to actively create the basis for the planned work. ${ }^{20}$ The restoration of Lochstedt Castle was started, along with the formation and arrangement of the museum (see below). Thanks to educational and lecturing activities in schools and unions (Vereine), in the first half of the year, Sommer succeeded in creating an entire network of like-minded volunteers, ${ }^{21}$ who in turn tried to arouse interest in the historical heritage among broad circles of the population of the district. The active search for and registration of artefacts, buildings and documents of cultural and historical value was carried out. The information obtained was also provided to the Prussia-Museum and the Prussian State Archive, which had similar goals concerning the research into and preservation of antiquities throughout the province, and

\footnotetext{
${ }^{18}$ In 1938, La Baume became head of the Land Department of Ancient History, which was established the same year (La Baume 1939, p. 281; Wagner 2019, p. 321).

${ }^{19}$ Marianne Huuck, personal communication.

${ }^{20}$ In his manuscript, Sommer provides a detailed account of the activities carried out by the Office between 1930 and 1945 in all the above-mentioned prioritised areas of historical and cultural heritage preservation. Within the framework of this article, however, we will focus only on activities directly related to the preservation of archaeological monuments in the Fischhausen district (and since 1939 in the district of Samland).

${ }^{21}$ For the time being, the question of the existence and the size of the official staff of the Office remains open. There is no direct mention of it in any currently known sources; however, indirect evidence suggests that Sommer might have had a professional assistant(s) for at least a period of time.
}

maintained close working contacts with the Office. In the light of the Office's mission to study genealogy and ethnography in the Fischhausen district, great importance was attached to the analysis of Church books, and preserved municipal and school chronicles, whose introduction was ordered by the Prussian government as early as 1790.

\section{The conduct of archaeological fieldwork and monument inventory}

At the same time, systematic work began on the discovery of archaeological sites in the region, especially of burial sites prior to the arrival of the Teutonic Order. Great attention was also paid to educational activities for the population: lectures in schools, and interaction with teaching staff, local mayors, and unions of peasants, landowners and gendarmes. The resulting maps of archaeological sites were presented for the first time in 1933 at the International Day of Geographers in Danzig. By May 1939, 244 cemeteries $^{22}$ had been registered in the Fischhausen district, and '... 124 of them urgently required conduction of archaeological excavations' (Sommer 1956, p. 13). ${ }^{23}$ The Office received information about the new finds either directly from the finders and the owners of the land on which the monuments were discovered, or from the volunteers educated by Sommer. As was mentioned above, the active exchange of information took place with the Prussia-Museum, ${ }^{24}$ and later on also with the Land Department of Ancient History, which was established 1938 and grew out of the Ancient History Section (Vorgeschichtliche Abteilung) of the Prussia-Museum, with La Baume as the department's head (La Baume 1929, p. 281; Wagner 2019 , p. 319). The active assistance of the local population in the detection and preservation of monuments to a certain extent counterbalanced the lack of financial and human resources of the Office, which was not able to conduct field studies of the ever-increasing number of detected

${ }^{22}$ An interesting observation is the underrepresentation of data on hillforts in the finds card-index (despite the presence of numerous monuments of this category in the region of interest), which should most likely be explained by Sommer's knowledge of the work on the recording of hillforts already carried out at that time by his colleagues (Wagner 2019, pp. 267-269).

${ }^{23}$ The quote from Sommer's manuscript most likely means that the mentioned 124 monuments were in immediate danger of destruction because of ongoing or planned agricultural or other activities.

${ }^{24}$ This harmonious and mutually beneficial relationship between the two museums, one of which, in modern business language, was the founder and the other a subsidiary, is, in many ways, indicative. In a number of other cases, the relationships between small local museums (Heimatmuseen) and the PrussiaMuseum had rather a competitive character (Wagner 2019, pp. 302-307). 


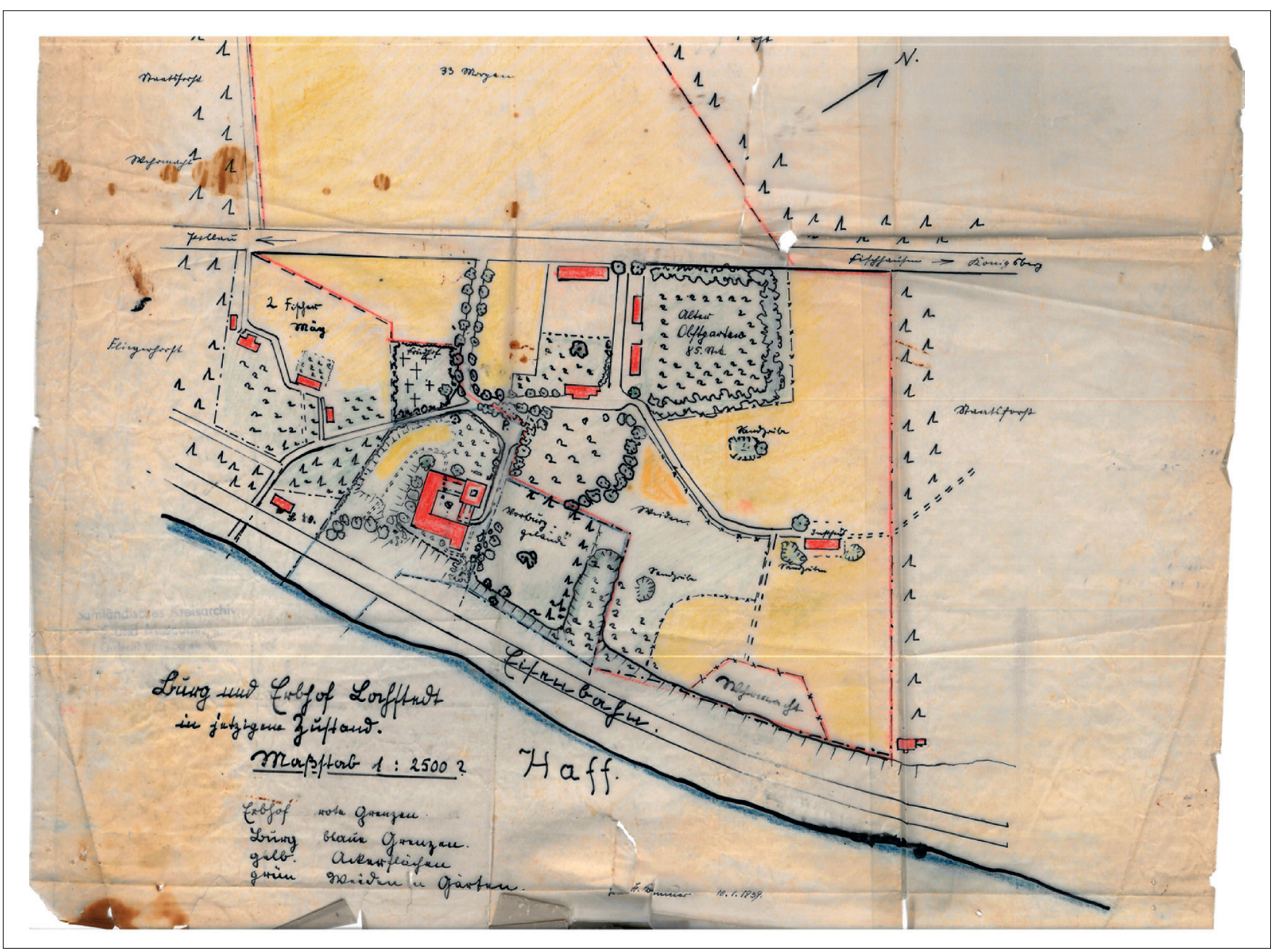

Figure 4. A general plan of Lochstedt Castle, 1939 (drawn by H. Sommer).

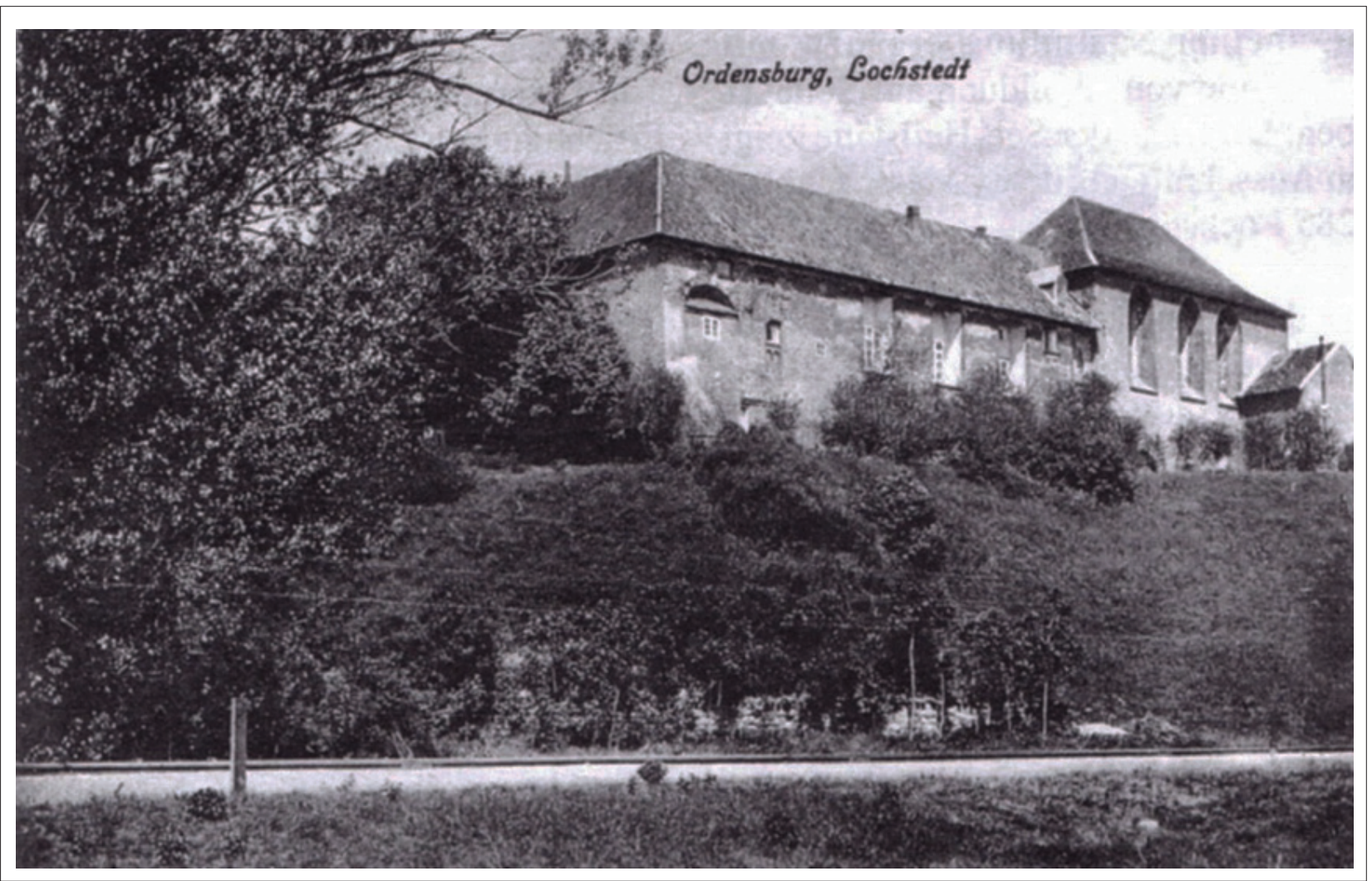

Figure 5. Lochstedt Castle (photograph from the legacy of H. Sommer). 


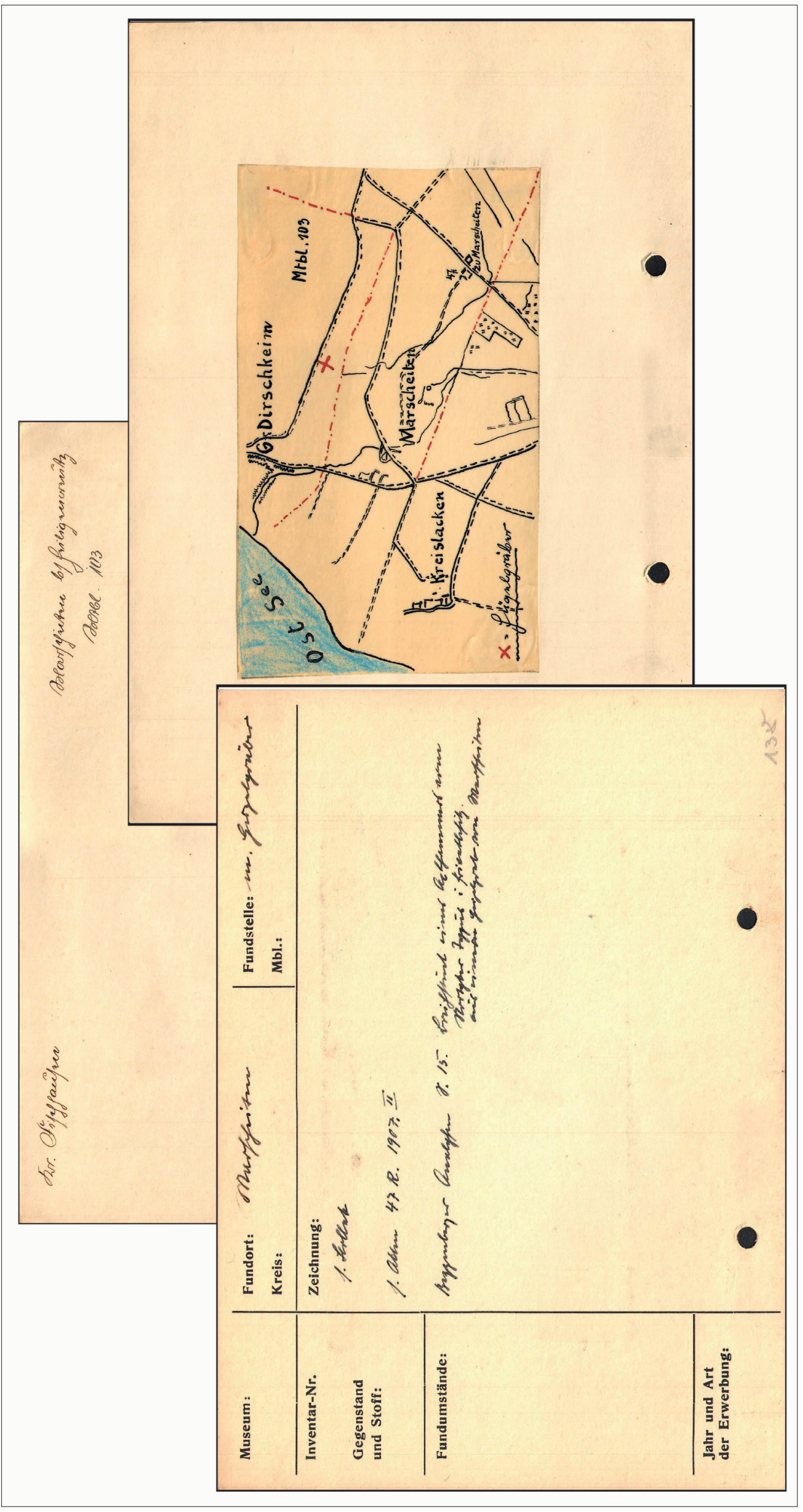

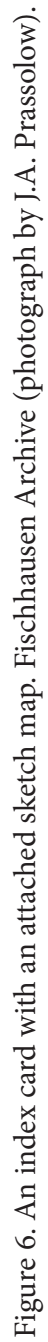


archaeological sites to the desired degree. ${ }^{25}$ According to the recollections of his daughter, Sommer spent far more time visiting newly discovered archaeological sites and educating local people than even with his own family. ${ }^{26}$

The most important data on the monuments identified were entered in a card-index archive (Fig. 1). If accurate information about a monument's location was available, a schematic sketch map of the site was glued to the reverse side of the respective index card. The sketch was made on a piece of parchment paper and provided with a graphic symbol, which was specific to the category of discovered monument, and marked the spot where it was situated (Fig. 6). The location of the archaeological monument was also recorded on full-scale topographical maps (scale 1:25000), which served as a basis for the creation of the sketch maps described above.

\section{Anthropological research}

Another interesting research project by the Office was the reconstruction of the anthropological appearance of the ancient Prussians, the indigenous population of Samland. The last studies of this kind were carried out on local material in the last quarter of the 19th century, and did not meet the increased research requirements of the 1930s, because of the selectivity of the bone material inspection. A necessary prerequisite for modern research was the study of complete human skeletons, and this finally became possible thanks to archaeological excavations at an 'undoubtedly Old Prussian burial site in the winter of 1932-1933 (Sommer 1956, p. 13): the well-preserved skeletons of eight individuals were found. The results of the investigations were documented in the form of a report, and sent to a number of research institutions.

\section{Museum activities}

The establishment and further development of the public museum in the Order's Lochstedt Castle ${ }^{27}$ were of great importance for the promotion of the archaeological heritage, as well as for instilling a sense of responsibility for its preservation among the local population. Sommer, who was also the officially appointed curator of the castle, worked tirelessly in this direction. In 1934, the exhibition received a thematic expansion with a section devoted to

\footnotetext{
25 The number of find reports increased further after 1933, due to the National Socialists' appeal to the image of heroic antiquity, and due to the popularisation of archaeology for propaganda purposes as a result. For the same reason, the number of archaeological excavations conducted in the province also increased, starting from 1933 (Bohnsack 1938; Nowakowski 2000, p. 204)

${ }^{26}$ Marianne Huuck, personal communication.

${ }^{27}$ Heimat Museum des Kreises Samland, Burg Lochstedt (La Baume 1942, p. 42). The name of the museum was most likely the same until 1939, except for the district's name.
}

amber. By 1939, the list of topics covered by the exhibition had grown even bigger. Accordingly, whereas in 1930 the complete archaeological exhibition of the museum was displayed in only three rooms, by 1939 the exhibition occupied 13 rooms. And this is despite the fact that, as Sommer loved to repeat later, there were only three keys to the castle gates at the time of the museum's establishment (Sommer 1956, p. 16)! The opening of the museum's exhibition as early as 1931 became possible largely due to close cooperation with the Prussia-Museum, whose director Gaerte loaned a large number of exhibits from the Prehistoric and Order periods to the Lochstedt museum. At the same time, thanks to archaeological excavations and other investigations performed by the Office, the museum's own collection acquired impressive dimensions just a few years after its foundation. Medieval finds were particularly numerous: ceramic and glass vessels in various forms, shaped bricks, tiles, etc. The number of field records, sketches, photographs and other documentation in the museum's archive increased rapidly, proportionally to the volume of work carried out.

\section{Sommer and the Office's archaeological material during the Second World War}

The outbreak of the Second World War forced the cessation of all the Office's work, because of Sommer's conscription, as a reserve officer, into the army. ${ }^{28}$ In 1943, after being wounded, he was transferred back to Königsberg, where he was appointed director of the Army Museum (Heeres-Museum). By this time, preparations for defence in the province were already in full swing. According to the plan of the local Wehrmacht command, Lochstedt Castle was made part of the defence system. During Sommer's absence as the warden of the castle, a garrison and an anti-aircraft battery were placed in it, making Lochstedt an important target for Allied bombing in the vicinity of Fort Pillau. The final decision to relocate the battery and move the garrison from the castle was made only at great cost.

At the same time, according to an agreement with the director of the Prussian State Archive in Berlin, a part of the Secret Archive of the German Reich, a significant part of the Königsberg State Archive, and some Polish Church ar-

\footnotetext{
${ }^{28}$ We do not have reliable information at present on the preservation of monuments in the Samland district for the period between the mobilisation of Sommer and his return from the front in 1943. La Baume mentioned in a short article published in 1942 a teacher called Fritz Grigat (II), from Gamsau, to the north of Legnen, as the second person responsible for the state of monuments in the Samland district (La Baume 1942, p. 29). Taking into account the geographical location of Gamsau in the very south of the Samland district, it may be assumed that Grigat was primarily responsible for the preservation of archaeological monuments in the former Königsberg district.
} 


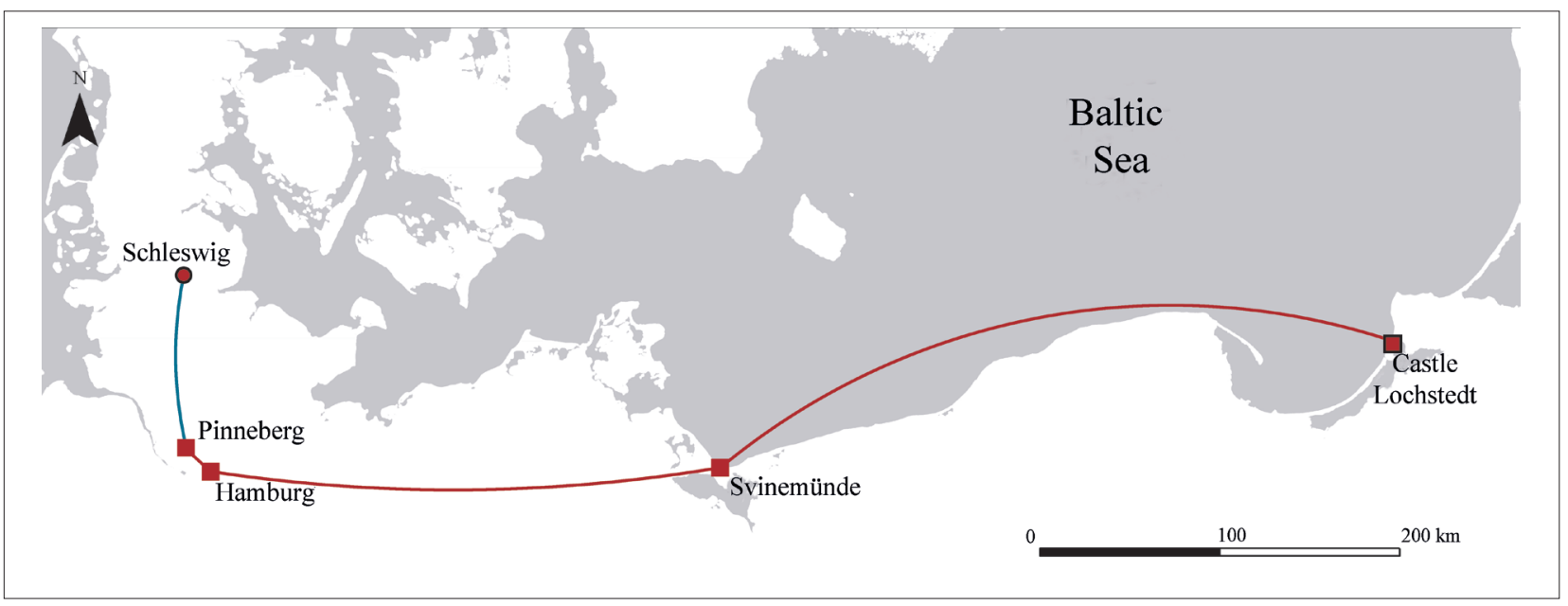

Figure 7. The evacuation route of Hermann Sommer in April 1945 (drawn by J. Nowotny).

chives, were moved to Lochstedt. Also, the collection of the Königsberg Army Museum and its archive, as well as the most important Church archives from the district of Samland, were stored there.

In August 1944, the Red Army units crossed the border of the German province of East Prussia. Despite the fact that the front line continued inexorably to approach Lochstedt Castle, the evacuation of the collections and archives was not possible, due to the lack of available human resources and vehicles (i.e. not engaged in building defences), as well as for political reasons. The political leadership of the province defiantly denied the possibility of surrendering to the advancing Red Army, and considered all plans for the evacuation of cultural and historical property as defeatist. As a result, by the time the castle was occupied by the Red Army, almost all the archives mentioned above, as well as the collection of archaeological finds and the archives of the Office, had still not been evacuated. Thanks to the temporary breakthrough by German troops of the encirclement of the town, Sommer, who had served in Königsberg since his return from the front in 1943, was able to return to the Office on 26 February 1945. The interior of the castle, vacated by Red Army units and already occupied again by German troops, had suffered destruction and was in chaos. Despite all his efforts, in the prevailing atmosphere of an impending military disaster, Sommer only managed to restore relative order.

The Königsberg garrison surrendered on 9 April 1945. Sommer managed to escape from the city, and returned to Lochstedt. There, collections and archives were carried away under artillery fire for storage in the basement, and given explanatory inscriptions in Russian for the advancing Red Army troops. On 16 April 1945, Sommer received permission to leave East Prussia and go to the German province of Schleswig-Holstein. Although he had permission to take only hand luggage, he managed to take several suitcases (!) with archival materials and some archaeological finds, ${ }^{29}$ as well as his personal library about the Teutonic Order's period of rule in the region with him. ${ }^{30}$ He managed to load this cargo on board a steamship only by force of arms. After the sinking of the first ship, the suitcases were loaded with just as much difficulty onto another steamboat going to Swinemünde, where the military police almost threw them overboard from the overloaded ship. After his arrival in Hamburg on 23 April 1945 (Fig. 7), Sommer was finally appointed to the small town of Pinneberg as the commandant of a section of the city (Abschnittskommandant). In this capacity, he was captured by one of the tank units of the advancing British Army, while the archive and other materials he had taken out of Lochstedt Castle were confiscated. However, Sommer's luck did not desert him, and a few days later, he managed to persuade a Hungarian officer to retrieve the documents from the local headquarters of the British Army, and to take them to a safe place.

Summing up the results of

the archaeological research after the war

In the early postwar years, the inhabitants of the former East Prussia who now lived in the part of Germany controlled by the Allies ${ }^{31}$ had a strong sense of the tempo-

${ }^{29}$ The artefacts, including several swords from the Viking Age and the Teutonic Order period in the region, can be viewed in the small exhibition of the Fischhausen Community in Pinneberg.

${ }^{30}$ The above-ground part of the castle was severely damaged just a few days later, during the fierce fighting in the area around Pillau. No reliable data on the fate of the archaeological collection and the archival materials that remained in the castle are currently available (Bakhtin 2005, p. 118; Konstantin Skvortsov, Kaliningrad archaeologist, personal communication).

${ }^{31}$ This applies both to people who left the province on their own or were evacuated from East Prussia in the last months of the 


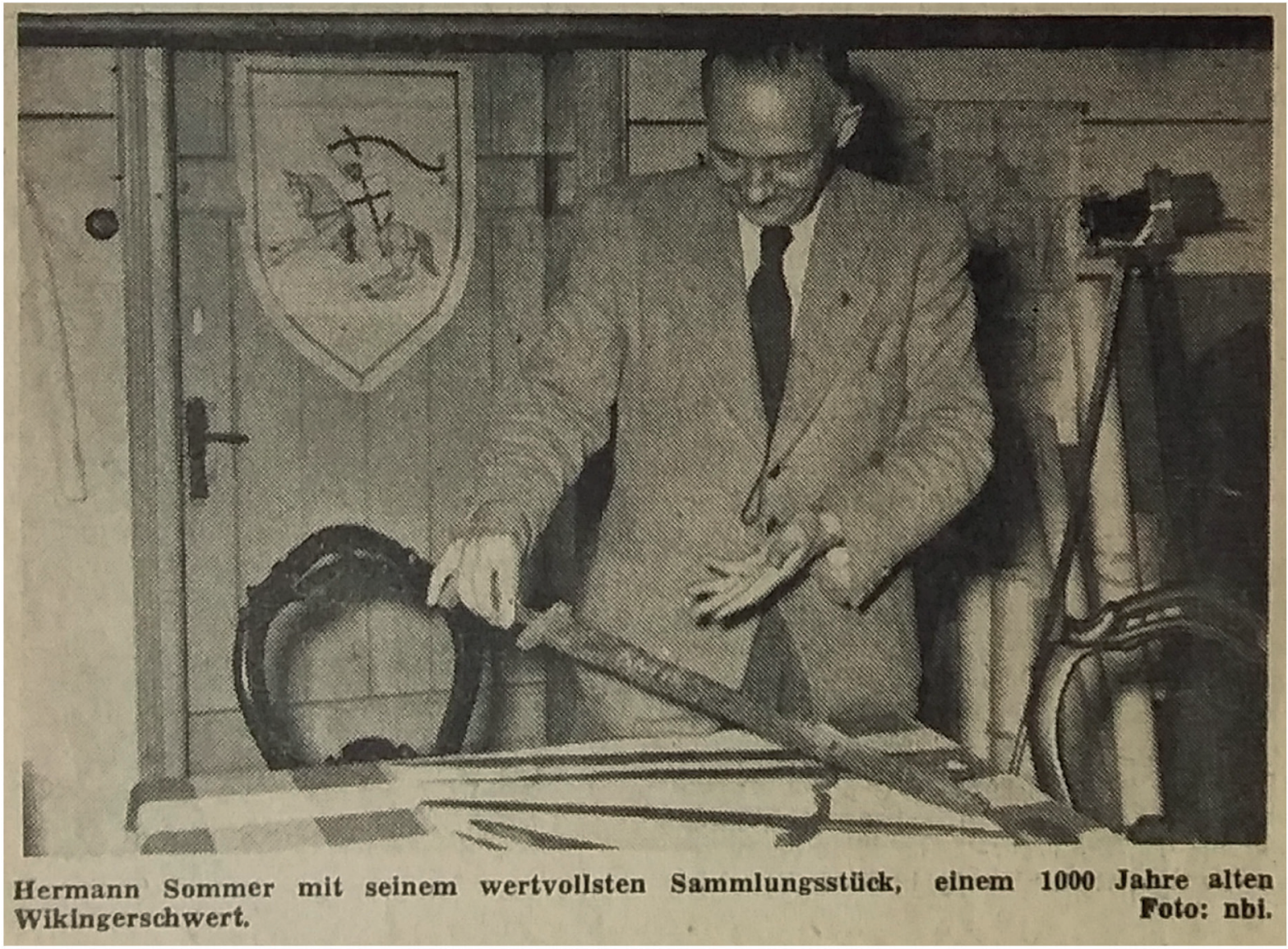

Figure 8. Hermann Sommer shows one of the Viking Age swords saved from Lochstedt Castle in 1945 (photograph by I. NeumannBinné in 1955).

rariness of their refugee status. Most were convinced that political relations between the countries-participants in the Second World War would be normalised in the next few years, and that the people of East Prussia would be able to return home. This hope was also shared by Sommer, who considered his work on the systematisation and analysis of the evacuated archaeological materials, ${ }^{32}$ which he started immediately after his release from captivity in June 1945, as a preparation for the forthcoming resumed research into the antiquities of the Samland district. His activities therefore focused on the systematisation of the evacuated archival materials, and the analysis of the data in them (Fig. 8). In the meantime, he created and headed the Working Society of the Samland district (Arbeitsgemeinschaft Kreis Samland) in Pinneberg, and a little later founded the Archive and Museum of the Samland district. ${ }^{33}$ In addition, after the foundation of the Local Com-

war, and to inhabitants of the province who were deported to Germany between 1947 and 1951.

32 This collection of rescued archival materials and finds was later given the informal name Hort- und Depotfund in the Pinneberg museum (Lienert-Emmerlich 2003, p. 90).

${ }^{33}$ The archive and museum were created primarily for the purpose of preserving exhibits and documents related to the Sambian region (Landschaftsbezirk Samland), which included the munity of East Prussia (Landesmannschaft Ostpreußen), Sommer was elected official representative and head of the Fischhausen Community, a position he retained until his death in 1962.

The archaeological legacy of Sommer and its research potential

As described in the beginning of this publication, the first thing that received our attention was the Fischhausen card-index archive of archaeological monuments. Personal contact was recently established with Sommer's family, and with the staff of the Archive and Museum of the Samland district in Pinneberg. Both contacts handed over a number of further archival materials, including the unpublished manuscript written by Sommer on which this paper is largely based. The manuscript not only sheds light on the prewar phase of archaeological research on Samland, but also describes it from quite a new perspective. In addition, it gives a detailed overview of the main directions of research conducted by the Office, as well as

district of Fischhausen, the rural district and city of Königsberg, and the district of Labiau (Sommer 1956, p. 23). 


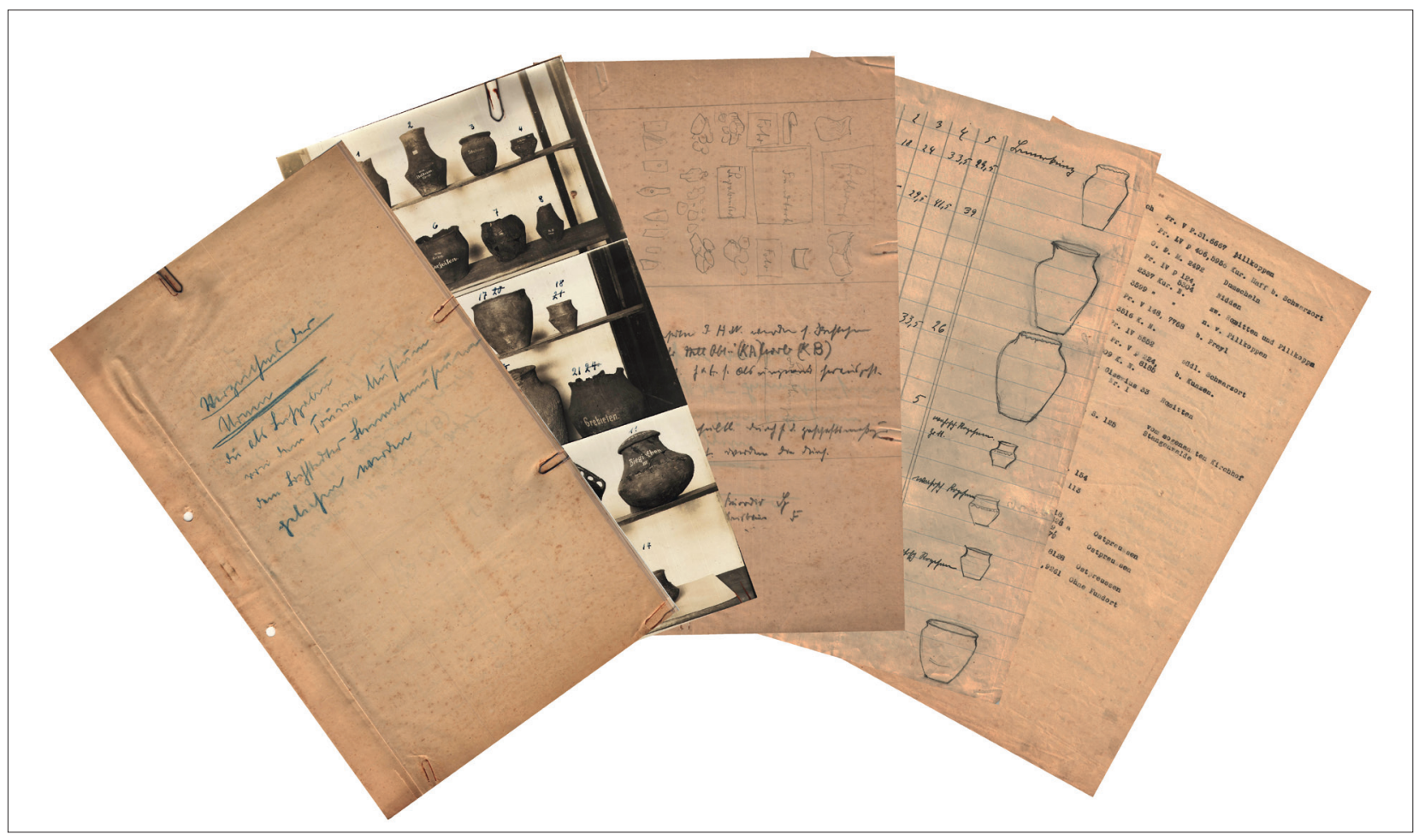

Figure 9. A list of artefacts from the Prussia-Museum exhibited in Lochstedt Castle. Archival materials from Sommer's legacy.

demonstrating the nature of the archaeological materials rescued by Sommer in 1945. It has steadily become clear that Sommer's archive at the Museum für Archäologie Schloss Gottorf was only part of a much bigger legacy. Understanding this fact served as a trigger for the search for the rest of it, which continues up to this day.

To sum up, we have succeeded to date in discovering the following archival materials from Sommer's archaeological legacy, which were donated to the Museum für Archäologie Schloss Gottorf by his family and the Fischhausen Community:

a) a list of artefacts loaned to the museum in Lochstedt by the Prussia-Museum (Fig. 9). The schematic drawings and photographs supplement the list of ceramic vessels. This extremely interesting document not only gives an idea of the exhibits in Lochstedt Castle, but also contributes to a reconstruction of the Prussia-Museum collection of finds;

b) a repeatedly cited manuscript report by Sommer on his archaeological activities in the Fischhausen district from 1929 to 1945 , and during the postwar years. This report is to date the only known document describing the establishment and activities of the Office;

c) reporting documentation on anthropological studies of skeletons from inhumations carried out during the winter of 1932-1933 (Fig. 10); d) records concerning archaeological excavations of the Sorthenen I flat burial site in the Fischhausen/Samland district (Fig. 11);

e) documentation from the archaeological excavations at Lochstedt Castle;

e) a list of coin finds preserved at Lochstedt Castle;

g) other archival materials (documents and dias).

In addition, shortly before this publication was finished, a list of archaeological sites in the district of Fischhausen, written down in the winter of 1929-1930, was given to the Archaeological Museum by Wolfgang Sopha, the head of the Fischhausen Community. This document was based on records in the archive of the Prussia-Museum, and represents a prototype of the four-volume card-index archive created by Sommer, which took into account archaeological research carried out in subsequent years.

\section{Conclusions}

The first work with the materials from Sommer's legacy, which are presented now to the modern archaeological community for the first time, has already shown their great potential for the reconstruction of the prewar state of research, as well as for the present and future archaeological investigation of the Kaliningrad Peninsula. These data 


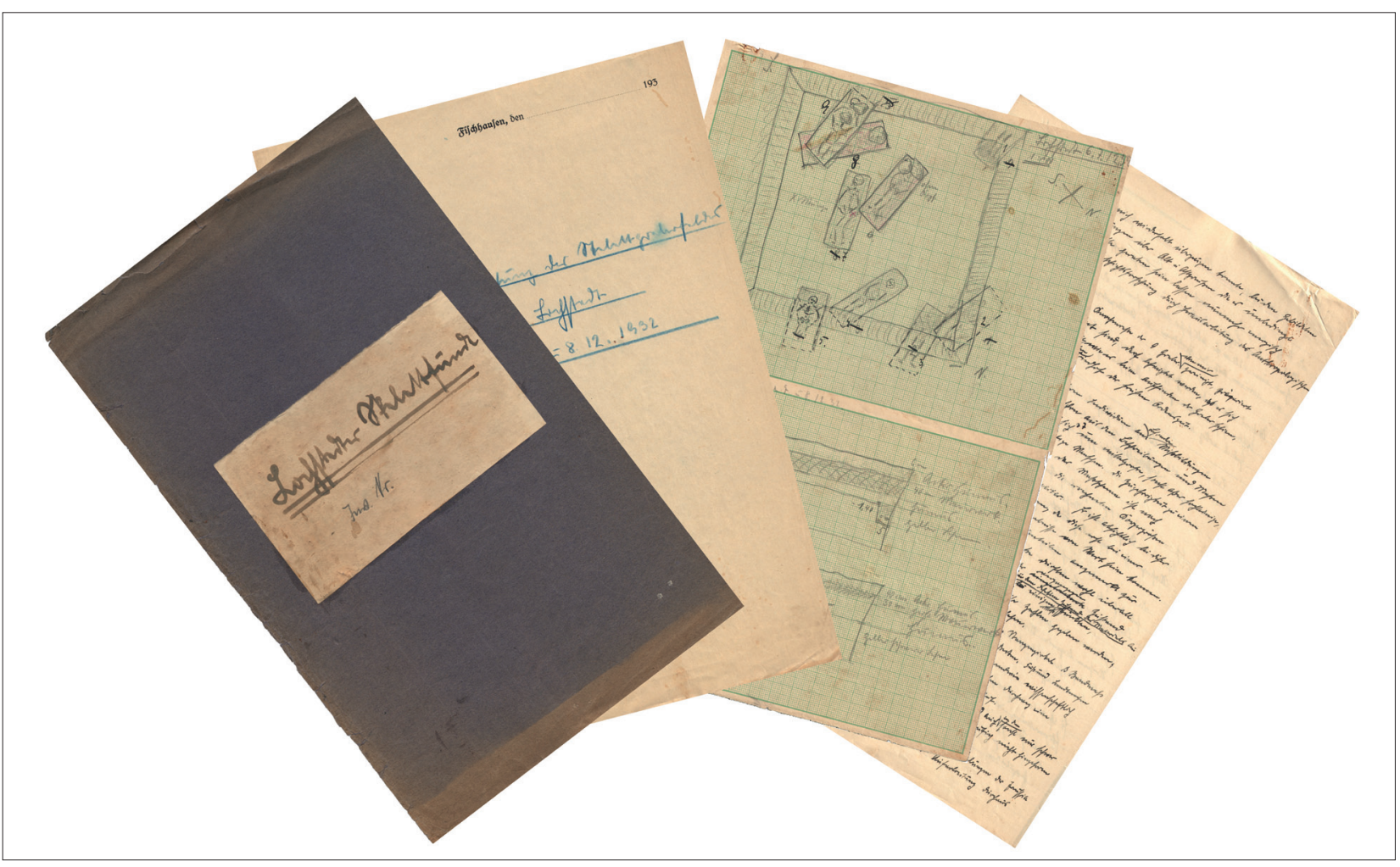

Figure 10. A report on the anthropological studies of skeletons excavated in the winter of 1932-1933. Archival materials from Sommer's legacy.
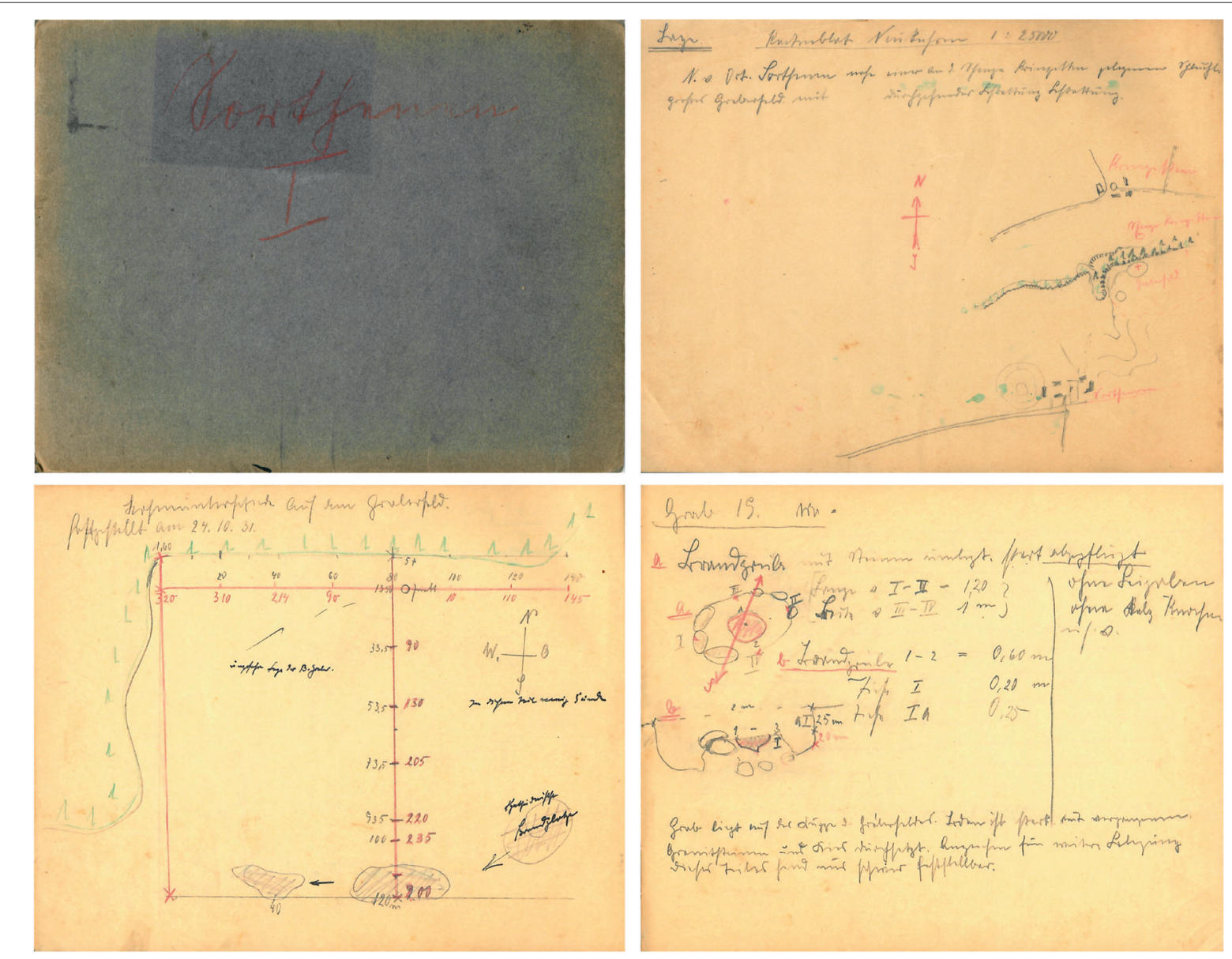

Figure 11. Records of the archaeological excavations at the Sorthenen cemetery in the district of Fischhausen/Samland. Archival materials from Sommer's legacy. 
perfectly complete the information on the category and location of archaeological monuments in the Fischhausen district, which can be found in the rediscovered partially preserved archive of the Prussia-Museum, as well as in prewar publications.

To date, all currently available materials from the researcher's legacy have been digitised, which, on one hand, guarantees their further long-term preservation, and, on the other hand, simplifies their research analysis. ${ }^{34}$ Over the past few years, the Fischhausen Archive has been actively used in the reconstruction of the archaeological landscape of the modern Kaliningrad Peninsula. Superimposing the sketch maps of the monuments on prewar German maps, as well as on modern topographical maps in the Geographic Information System (GIS), allows us to accurately reconstruct the locations of archaeological sites known before 1945, and to perform a preliminary assessment of their preservation, as well as to prioritise the order of their future investigation.

In addition, the general report on Sommer's activity (and that of the Office) in the years 1929 to 1945, as well as further working reports written by the archaeologist, significantly add to our understanding of the motivation and principles of the preservation of cultural monuments and interaction between research and museum institutions in the former province of East Prussia.

Besides that, a number of remarks made by Sommer in his manuscript, some data published by him after the war (Sommer 1959, pp. 76-79), and short reports in West German regional newspapers and journals, whose journalists interviewed him in the 1950s (Neumann-Binné 1955; Mosler-Boehm 1957; Fischer 2000; Lienert-Emmerlich 2003 , pp. $92,93,95,96$ ) allow us to presume the existence of further archival materials (documents, archaeological maps and slides) from Sommer's legacy, which have yet to be discovered and (re-)introduced into scientific research.

In conclusion, the author would like to draw the attention of readers to another very curious and important remark in the manuscript by Sommer. The East Prussian archaeologist mentions that the experience of the Fischhausen district, which established the Office for the Care and Preservation of the Cultural Heritage, was later copied by

\footnotetext{
${ }^{34}$ The author would like to mention his great appreciation for the big contribution made by his colleague Jörg Nowotny, from the GIS-Department of the Centre for Baltic and Scandinavian Archaeology (ZBSA), who took part enthusiastically in many research activities connected with the work on the legacy of Hermann Sommer: the search for the archival materials, their digitalisation, i.e. their long-term preservation and decoding, as well as the implementation of the rediscovered data on the location of the archaeological monuments, both for the reconstruction of the ancient archaeological landscape in the district of Fischhausen/Samland and GIS-based mapping.
}

several other administrative districts in the former East Prussia (Sommer 1956, p. 10). This observation suggests that similar archives were created by local archaeologists (heads of similar offices?) in other districts of the province. If this assumption is confirmed, and the corresponding archival materials from other districts can be found in the archives of research institutions and state museums, as well as in the archives and collections (Heimatstuben and Heimatsammlungen) of East Prussian local communities, or even of private individuals, it will be possible to reconstruct the prewar state of archaeological research also in these regions of the former province on a fundamentally higher level. And this is indeed a case when the help of the curators of modern museums and archives, as well as the people of East Prussia and their descendants, would be invaluable. According to the good East Prussian tradition, the high-quality archaeological research of the region cannot be imagined without the close cooperation of professional archaeologists and citizens interested in preserving their cultural heritage.

\section{References}

Manuscripts

Sommer, H., 1956. Unpublished manuscript. Pinneberg. Sommer, H., 1959. Der Samlandkreis Fischhausen. Pinneberg.

\section{Literature}

Bakhtin, A. P., 2005. Zamki i ukreplenia Nemetskogo ordena $v$ severnoĭ chasti Vostochnoı̆ Prussii. [Castles and fortifications of the Teutonic Order in the northern part of East Prussia. $]^{35}$ Kaliningrad: Terra Baltika.

La Baume, W., 1942. Die Bodendenkmalpflege in Ostpreußen. Alt-Preußen, 7 (2), 29.

La Baume, W., 1942. Die ostpreußischen Heimatmuseen. AltPreußen, 7 (2), 30-31.

La Baume, W., 1939. Vorgeschichtliche Forschung und Denkmalpflege in Ostpreußen, 1938. Nachrichtenblatt für Deutsche Vorzeit, 15 (11/12), 281-286.

Bohnsack, D., 1938. Der Arbeitsdienst und die Ostpreußische Vorgeschichtsforschung. Altpreußen, 3 (1), 11-12.

von Carnap-Bornheim, C., Wemhoff, M., Eilbracht, H., Prassolow, J.A., Ibsen, T., 2012. Continuity of research and research of continuity: basic research on settlement archaeology of the Iron Age in the Baltic region. A new long-term research project by the Academy of sciences and literature in Schleswig and Berlin. Archaeologia Baltica, 17, 16-20.

Dunker, H., 1927. Mehr Denkmalschutz und Heimatpflege. Nachrichtenblatt für Deutsche Vorzeit, 3, 33-34.

Fischer, W., 2000. Liebe Regehner Heimatfreunde. Unser schönes Samland. Samländischer Heimatbrief des Kreises Fischhausen und Landkreis Königsberg / Pr., 147, 67-74.

Grunwald, S., 2019. Archäologie im ehemaligen Ostpreußen als wissenschaftliche Herausforderung. Germania, 96, 235-244.

Hoffmann, M.J., 2018. Die Geschichte der Archäologie in Ostpreußen. Von ihren Anfängen im 18. Jahrhundert bis in das

${ }^{35}$ Hereinafter translations from Russian by the author. 
Jahr 1920. PRUSSIA-Schriftenreihe (Werk Nr. 44). Husum: Husum Druck.

Ibsen, T., Prassolow, J.A., Eilbracht, H., 2017. Ostpreußen reloaded. In: B. Eriksen et al., eds. Interaktion ohne Grenzen. Beispiele archäologischer Forschungen am Beginn des 21. Jahrhunderts, Vol. 2. Kiel/Hamburg: Wachholtz-Verlag, 819-831.

Jahn, M., 1927a. Verzeichnis der Vertrauensmänner für kulturgeschichtliche Bodenaltertümer in Preussen. Nachrichtenblatt für Deutsche Vorzeit, 3, 2-4.

Jahn, M., 1927b. Vorschläge zur Organisation und zum Ausbau der Denkmalpflege. Nachrichtenblatt für Deutsche Vorzeit, 3, 34-36.

Lienert-Emmerlich, H., 2003. Aus der Arbeit des Prussia im Samland. In: G. Brilla, ed. Zur Kulturgeschichte Ost- und Westpreußens. Prussia-Reihe, Werk 24. Husum: Husum Druckund Verlagsgesellschaft, 90-99.

Mosler-Boehm, L., 1957. Ostpreußische Heimatforschung heute. Samländisches Kreisarchiv und Museum setzt seine Arbeit fort - Bestände zum Teil gerettet. Königsberger Neue Zeitung (Ausgabe B der Ostpreußen-Warte), 10, 9.

Neumann-Binné, I., 1955. Wikingerschwert im feuchten Keller. Pinneberger Tageblatt, 229, no page number.

Nowakowski, W., 2004. Three centuries of Balt archaeology in East Prussia. Archaeologia Polona, 42, 65-102.

Nowakowski, W., 2000. Bodendenkmalpflege in den östlichen Provinzen Preußens vor 1945. Archäologisches Nachrichtenblatt, 5, 201-206.

Prassolow, J.A., Ibsen, T., 2015. Die Wiederentdeckung des verloren geglaubten Wissens. Rekonstruktion und Analyse der archäologischen Landschaft im ehemaligen Ostpreußen. Archäologische Nachrichten für Schleswig-Holstein, 20, 8-11.

Reich Chr., Menghin W., 2008. Die Prussia-Sammlung im Museum für Vor- und Frühgeschichte, Berlin. In: A. BitnerWróblewska, ed. Die archäologischen Inventarbücher aus dem ehemaligen Prussia-Museum. Aestiorum Hereditas I. Olsztyn: Archivum Panstwowe, 68-97.

Reich C., 2009. Verloren geglaubte Geschichte. Die PrussiaSammlung im Berliner Museum für Vor- und Frühgeschichte. In: A. Bitner-Wróblewska, C. von Carnap-Bornheim, J. Ciglis, V. Hilberg and W. Nowakowski, eds. F. Jakobson, Die Brandgräberfelder von Daumen und Kellaren im Kreise Allenstein, Ostpr. Neumünster: Wachholtz-Verlag, 347-361.

Wagner, W.D., 2019. Die Altertumsgesellschaft Prussia. Einblicke in ein Jahrhundert Geschichtsverein, Archäologie und Museumswesen in Ostpreußen (1844-1945). PRUSSIA-Schriftenreihe Bd. 29. Husum: Husum Verlag.

\section{HERMANNAS SOMMERIS IR \\ JO ARCHEOLOGINE KOLEKCIJA. 1929-1945 M. SEMBOS \\ PUSIASALIO KULTÜROS \\ OBJEKTU SAUGOJIMAS}

\section{JAROSLAW A. PRASSOLOW}

\section{Santrauka}

Šis straipsnis skiriamas Hermanno Sommerio (3 pav.), Kultūros paveldo apsaugos ir išsaugojimo organizacijos (Fischhausen regionas, Rytų Prūsija) ikūrèjo ir direktoriaus, mokslinei ir organizacinei veiklai 1929-1945 metais (2 pav.). Pristatomos organizacijos įkūrimo priežastys ir aplinkybès, jos archyvo gelbejjimo veiksmai ir galiausiai pristatomas po karo archeologu bendruomenès atrastas Sommerio istorijos ir archeologijos archyvas. Vadinamasis Fischhauseno archyvas yra pati vertingiausia rinkinio dalis (1 pav.). Tai iki 1945 m. Fischhauseno regiono suregistruotų archeologijos paminklų kartoteka.

Straipsnio autoriaus ir jo kolegų atlikta pirminè analizė atskleide dideli šio archyvo potencialą pažinti ir rekonstruoti ikikarinę tyrimų būklę ir suteikti daugiau žinių apie Kaliningrade esamus archeologijos objektus. Taip pat paaiškejo, kad Sommerio archyvas, kuris saugomas Archeologijos muziejuje Gottorf rūmuose Šlèzvige, yra tik nedidelè dalis Rytų Prūsijos archeologų palikimo (4-11 pav.). Tai sudarè prielaidas ieškoti kitų archyvo dalių ir atvedè prie netikètų atradimų. Paieška vis dar tęsiasi, tad ateityje tikimasi rasti ir kitų Rytų Prūsijos regionų archeologijos paminklų rinkinių. 